\title{
Associations of motor neuron disease research productivity and socioeconomic factors in Southeast Asia: a bibliometric analysis
}

\author{
Associações entre produtividade em pesquisa sobre doenças do neurônio motor e fatores \\ socioeconômicos no sudeste asiático: uma análise bibliométrica
}

Christian Wilson Rosales TURALDE', Adrian Isidoro ESPIRITU ${ }^{1,2}$, Roland Dominic Go JAMORA ${ }^{1,3}$

\begin{abstract}
Background: Scientific productivity on motor neuron disease (MND) research has been hypothesized to be low in Southeast Asia (SEA). Objective: To investigate the scientific productivity of SEA countries on MND and the associations between research metric indices and various country-specific socioeconomic parameters. Methods: We searched electronic databases for relevant articles from SEA on MND from the earliest indexed record to June 30, 2020. We obtained the following research productivity indices: bibliometric (number of publications in journals with impact factor (IF) and Scopus citations) and altmetric indices (PlumX metrics). We also collected data from published literature and reliable sources on the following socioeconomic variables: population, gross domestic product (GDP), GDP per capita, \%GDP allocated for research and development (R\&D) and the number of neurologists per country. Results: We included 196 articles that satisfied our inclusion criteria. Amyotrophic lateral sclerosis studies comprised the majority of the articles ( $n=112 ; 57.1 \%)$. The top three countries in terms of the numbers of publications in journals with IF and in PlumX metrics were Singapore $(n=129)$, Malaysia $(n=26)$, and Thailand $(n=18)$. GDP per capita, \%GDP for R\&D and number of neurologists per one million population had strong positive correlations with the bibliometric and altmetric indices. Conclusions: This study highlights that although the scientific productivity of MND research in SEA has been low, it is continuously growing. This also emphasizes the imperative to improve economic indices and the number of neurologists in SEA to enhance scientific output on MND.
\end{abstract}

Keywords: Motor Neuron Disease; Bibliometrics; Far East; Socioeconomic Factors.

\begin{abstract}
RESUMO
Antecedentes: A produtividade científica em pesquisa sobre doenças do neurônio motor (DNM) tem sido considerada baixa no sudeste asiático. Objetivo: Investigar a produtividade científica sobre DNM em países do sudeste asiático e as associações entre os índices métricos de pesquisa e vários parâmetros socioeconômicos específicos de cada país. Métodos: Foram consultadas bases de dados eletrônicas em busca de artigos relevantes sobre DNM provenientes do sudeste asiático, partindo do registro indexado mais antigo até 30 de junho de 2020. Obtivemos os seguintes índices de produtividade em pesquisa: bibliométrico (número de publicações em periódicos com fator de impacto (FI) e citações na base Scopus) e índices altmétricos (métrica PlumX). Também coletamos dados da literatura publicada e fontes confiáveis sobre as seguintes variáveis socioeconômicas: população, produto interno bruto (PIB), PIB per capita, \% do PIB alocada para pesquisa e desenvolvimento ( $P \& D$ ) e o número de neurologistas por país. Resultados: Selecionamos 196 artigos que atenderam aos nossos critérios de inclusão. Estudos sobre esclerose lateral amiotrófica representaram a maioria dos artigos ( $n=112 ; 57,1 \%)$. Os três principais países em termos de número de publicações em periódicos com Fl e em métricas PlumX foram Cingapura ( $n=129)$, Malásia $(n=26)$ e Tailândia $(n=$ 18). O PIB per capita, a \% do PIB para P \& D e o número de neurologistas por um milhão de habitantes tiveram fortes correlações positivas com os índices bibliométricos e altmétricos. Conclusões: Embora a produtividade científica em pesquisa sobre DNM no sudeste asiático ainda seja baixa, este estudo mostra que ela vem crescendo continuamente. Isto também enfatiza a necessidade de melhorar os índices econômicos e o número de neurologistas na região para aumentar a produção científica sobre o assunto.
\end{abstract}

Palavras-chave: Doenças do Neurônio Motor; Bibliometria; Extremo Oriente; Fatores socioeconômicos.

\footnotetext{
'University of the Philippines Manila, College of Medicine - Philippine General Hospital, Department of Neurosciences, Manila, Philippines.

¿University of the Philippines Manila, College of Medicine, Department of Clinical Epidemiology, Manila, Philippines.

${ }^{3}$ St. Luke's Medical Center, Institute for Neurosciences, Quezon City \& Global City, Philippines.

CWRT (1D https://orcid.org/0000-0001-7237-3728; AlE (1) https://orcid.org/0000-0001-5621-1833; RDGJ (D) https://orcid.org/0000-0001-5317-7369

Correspondence: Roland Dominic G. Jamora; Email: rgjmora@up.edu.ph.

Conflict of interest: There is no conflict of interest to declare.

Authors' contributions: CWRT: conceptualization, data curation, formal analysis, interpretation of data, writing-original draft, writing-review and editing. AlE, RDGJ: conceptualization, data curation, formal analysis, interpretation of data, writing-original draft, writing-review and editing.

Received on September 29, 2020; Received in its final form on December 09, 2020; Accepted on December 21, 2020.
} 


\section{INTRODUCTION}

Motor neuron diseases (MNDs) are a group of heterogenous disorders characterized by degeneration of upper and lower motor neurons, which causes progressive weakness and motor dysfunction and results in significant disability with a high fatality rate ${ }^{1}$. They consist of distinct disease entities such as amyotrophic lateral sclerosis (ALS) and its variants/mimics, i.e. progressive bulbar palsy (PBP), progressive muscular atrophy (PMA), primary lateral sclerosis (PLS), Madras motor neuron disease (MMND) and monomelic amyotrophy (MA); along with spinobulbar muscular atrophy (SBMA) or Kennedy disease, hereditary spastic paraplegia (HSP), spinal muscular atrophy (SMA) and post-polio syndrome (PPS $)^{2-5}$. ALS is the most common among the MNDs with a prevalence rate ranging from 4.1 to 8.36 per 100,000 population ${ }^{6,7}$. The overall all-age collective prevalence of ALS, PBP, PMA, PLS, HSP and SMA is 4.5 per 100,000 population, causing 926,090 disability-adjusted life-years ${ }^{1}$. The other MNDs are rare entities with prevalence rates of $<1$ in 1,000,000 population ${ }^{8,9}$.

Population-based and epidemiological studies on MNDs in Southeast Asian (SEA) populations are lacking, even though Asians comprise more than $50 \%$ of the world's population ${ }^{1}$. Furthermore, there is heterogeneity in terms of genetic pattern, clinical presentation and survival rate among patients with MNDs between Western and Asian populations ${ }^{10}$. In this context, there is an undeniable need to advance MND research productivity in Asia.

Scientific research productivity can be assessed using bibliometrics or the application of mathematics to analyzing patterns of citations, in order to measure the quality or impact of publications ${ }^{11}$. One of the traditional ways of measuring this is the journal impact factor (IF), a journal-level metric that is computed by dividing the total number of citations obtained by the total number of citable studies over two years ${ }^{12}$. Another way of assessing impact and productivity is through alternative metrics or "altmetrics", or quantitative study of scientific impact based on activities in the online environment such as numbers of downloads, views and mentions or tweets ${ }^{11}$. PlumX is a useful online tool that provides altmetric data in five categories: usage, captures, mentions, social media and citations ${ }^{13}$. The demand for use of such scientific productivity measurements has been increasing, given that these influence policymakers and funding agencies ${ }^{14}$.

Scientific productivity, as a measurement of innovation, has a significant positive relationship with economic growth ${ }^{15}$. Asian countries continue to shift from economies dependent on natural resources and primary commodities to researchdependent economies ${ }^{16}$. In SEA, the scientific productivity in MND research is still not well established because of a lack of published bibliometric analyses. It has been hypothesized that productivity in MND research in SEA is limited due to the low allocation of funding towards research and development ${ }^{16}$. There is a need for a study analyzing scientific productivity in MND research in SEA, to serve as an impetus for funding allocation, healthcare policy reform and scientific research promotion that are geared towards better clinical outcomes among patients with MNDs.

The objective of this study was to investigate the research performance of the SEA countries in MNDs, specifically ALS, PBP, PMA, PLS, MMND, MA, SBMA, HSP, SMA and PPS, in terms of bibliometric indices. Furthermore, this study aimed to investigate the associations between research metric indices and various country-specific socioeconomic parameters.

\section{METHODS}

\section{Inclusion criteria}

We included all published articles that used any study design such as experimental trials, quasi-experimental trials (non-randomized control studies, before-and-after studies or interrupted time series), observational-analytical studies (cohort studies, case-control studies or analytical cross-sectional studies), descriptive studies (qualitative or cross-sectional surveys), case series or reports, literature reviews, systematic reviews or meta-analyses. We excluded abstract-only publications, commentaries, editorials, conference proceedings, letters to the editor, book chapters, and incomplete or terminated studies. All studies involving humans conducted in any of the SEA countries (Brunei, Cambodia, Indonesia, Laos, Malaysia, Myanmar, Philippines, Singapore, Thailand, Timor-Leste and Vietnam) or animal models for MNDs or in-vitro laboratory studies on pathophysiology, genetics, pathology, clinical presentation, diagnosis, treatment and prognosis of ALS and its mimics or variants (PBP, PMA, PLS, MMND and MA), SBMA, HSP, SMA and PPS with at least one author affiliated with any institution in the SEA countries that were published in English, or in any other language provided that they had an English abstract, were considered for inclusion.

\section{Search methods and study selection process}

We searched the following electronic databases for relevant articles: MEDLINE via PubMed, Scopus, Cochrane Central Register for Controlled Trials (CENTRAL), EMBASE, ClinicalTrials.gov website and Western Pacific Region Index Medicus (WPRIM). We included articles on MNDs from the earliest indexed record up to June 30, 2020. The following MeSH term-based search strategy was used: ["motor neuron disease" OR "amyotrophic lateral sclerosis" OR "progressive bulbar palsy" OR "progressive muscular atrophy" OR "primary lateral sclerosis" OR "Madras motor neuron disease" OR "monomelic amyotrophy" OR "spinobulbar muscular atrophy" OR "hereditary spastic paraplegia" OR "spinal muscular atrophy" OR "post-polio syndrome"] AND [Brunei OR Cambodia OR Indonesia OR Laos OR Malaysia OR Myanmar OR Philippines OR Singapore OR Thailand OR Timor-Leste OR Vietnam]. To ensure systematic search saturation, related keywords were 
also used. We excluded duplicate entries. The remaining studies were screened and articles that were not about MNDs were excluded. The full-text articles of the remaining entries were retrieved and were subjected to eligibility testing using predefined eligibility criteria.

\section{Bibliometric and altmetric indices included}

The following bibliometric indices were considered in this study: total number of publications per country, total number of publications in journals with IF and Scopus citations ${ }^{17}$. PlumX metric data were used to analyze the altmetric indices ${ }^{18}$. The impact factors of journals were obtained from Clarivate Analytics' 2020 Journal Citation Reports ${ }^{19}$. PlumX metric data are organized into five distinct categories, as follows: (a) usage, an article-level metric that includes the number of abstract views, number of downloads and number of clicks; (b) captures, which includes the number of times that the material is bookmarked, exported or favorited; (c) mentions. which includes the number of comments that the material had in media or blogs; (d) social media metrics, including the number of tweets, likes or shares that the material had in different social media platforms; and (e) citations ${ }^{20}$.

\section{Socioeconomic factors included}

Population, gross domestic product (GDP), GDP per capita and percentage (\%) GDP allocated to research and development $(R \& D)$ for each SEA country were obtained from the official website of the World Bank ${ }^{21}$. The number of practicing neurologists per SEA country was based on recently published data ${ }^{22}$.

\section{Data collection and analysis}

The following information was obtained for each of the studies included: SEA country and institution where the author(s) is/are affiliated, year of publication, journal in which the article was published, journal IF, type of MNDs investigated (ALS and its mimics/variants [PBP, PMA, PLS, MMND and MA], SBMA, HSP, SMA or PPS), domain (pathophysiology, clinical features, diagnosis, treatment, prognosis or psychosocial aspects) and study design used. Statistical analyses were performed using IBM $^{\circledR}$ SPSS ${ }^{\bullet}$ Statistics for Macintosh Version 24 (IBM Corp., Armonk, NY, USA). The data derived from the socioeconomic, bibliometric and altmetric indices were expressed as counts/ frequencies and percentages. Bivariate correlations between socioeconomic indices and bibliometric and altmetric indices were obtained using two-tailed Pearson's R coefficient.

\section{RESULTS}

A total of 2,534 studies were obtained using the MeSH termbased search strategy (PubMed: 164; Scopus: 2,285; CENTRAL: 3; EMBASE: 72; ClinicalTrials: 3; and WPRIM: 7). After duplicates $(n=154)$ were removed, a total of 2,380 articles were screened. An additional 7 articles were excluded (incomplete/ terminated trials, $n=3$; veterinary MNDs, $n=4$ ). The full texts of the remaining 2,373 articles were obtained and were assessed for eligibility. All indexed studies retrieved had been published in the English language. A total of 196 studies satisfied the inclusion criteria and were thus included in the analysis. Figure 1 shows the PRISMA flow diagram.

\section{Characteristics of studies included}

The majority of the studies included were investigations of ALS ( $\mathrm{n}=112 ; 57.1 \%)$. The distribution of studies in terms of the other types of MND investigated were as follows: SMA ( $\mathrm{n}=$ $41 ; 20.9 \%)$, more than one type of MND ( $n=31 ; 15.8 \%)$, SBMA $(n=6 ; 3.1 \%)$, PPS $(n=2 ; 1 \%)$ HSP $(n=1 ; 0.5 \%), \operatorname{MMA}(n=1$; $0.5 \%), \operatorname{MMND}(\mathrm{n}=1 ; 0.5 \%)$ and PLS $(\mathrm{n}=1 ; 0.5 \%)$. There were no studies on PBP, PMA or MA that satisfied the inclusion criteria. The earliest indexed record was published in 1980. There had been a consistently growing number of publications on MNDs in SEA up to the time of writing (see Figure 2).

In terms of study design, the distribution was as follows: laboratory $(n=73 ; 37.2 \%)$, review of literature $(n=54 ; 27.5 \%)$, cross-sectional study $(n=22 ; 11.2 \%)$, case report/series $(n=21$; $10.7 \%)$, case-control study $(n=9 ; 4.6 \%)$, retrospective study $(n=$ $8 ; 4.1 \%)$, systematic review/meta-analysis $(n=4 ; 2 \%)$, prospective study $(n=4 ; 2 \%)$ and clinical trial $(n=1 ; 0.5 \%)$. The majority of the included studies investigated pathophysiology ( $n=99$; $50.5 \%)$. The rest investigated treatment $(\mathrm{n}=36 ; 18.4 \%)$, diagnosis ( $\mathrm{n}=21 ; 10.7 \%)$, natural history/prognosis $(\mathrm{n}=17 ; 8.7 \%)$, clinical features $(n=10 ; 5.1 \%)$, epidemiology $(n=9 ; 4.6 \%)$ and psychosocial factors $(n=4 ; 2 \%)$.

\section{Journals and institutions with the highest numbers of published studies on MNDs in SEA}

A total of 122 journals published studies on MNDs in SEA. Brain Development and Kobe Journal of Medical Sciences published the largest numbers of studies on MNDs in SEA (see supplementary material). Among the SEA institutions, the National University of Singapore published the largest number of articles on MNDs ( $\mathrm{n}=80 ; 40.8 \%$ ), followed by Nanyang Technological University of Singapore ( $\mathrm{n}=9 ; 4.59 \%)$ and Universiti Sains Malaysia ( $\mathrm{n}=8 ; 4.08 \%$ ) (see supplementary material).

\section{Socioeconomic factors for each SEA country}

In the 2019 population estimate, the SEA region had a total population of 669.96 million. Indonesia, as the most populous SEA country (270.63 million), contributed the largest proportion of GDP in SEA (1.19 trillion USD) ${ }^{21}$. It also had the highest number of neurologists $(1,150)^{22}$. In terms of the ratio between the number of neurologists and the population size, Singapore had the highest with a ratio of approximately 18 neurologists per one million population, followed by Thailand and Vietnam. In terms of population-influenced productivity, Singapore also appeared to be most productive, with GDP per capita of 65,233.30 USD. In terms of research expenditure, Singapore had 


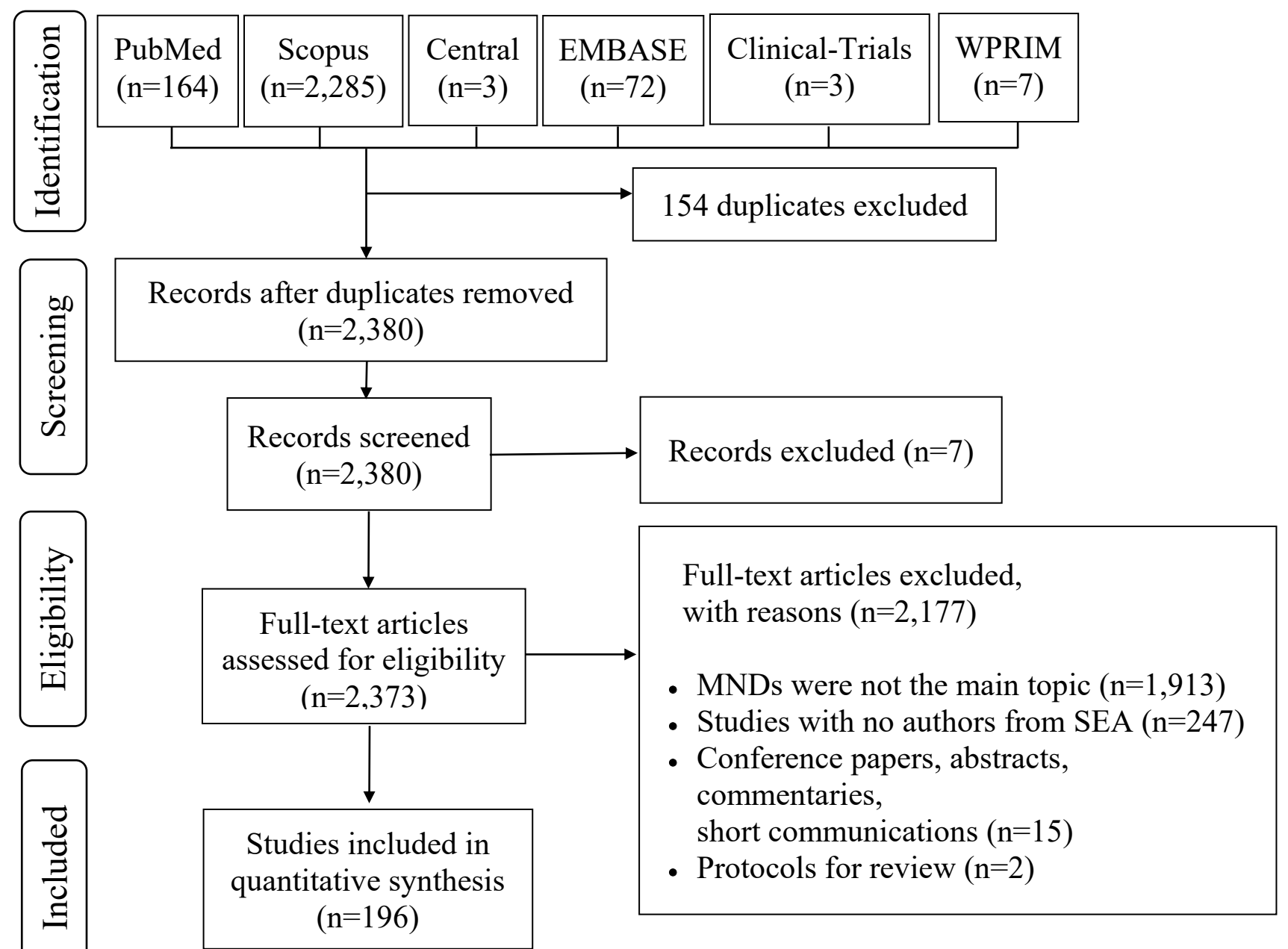

Figure 1. PRISMA flow diagram for study selection.

the highest allocation of GDP for research (1.94\%), followed by Malaysia (1.44\%) and Thailand (1.00\%). Table 1 summarizes the selected socioeconomic indices of the SEA countries.

\section{Bibliometric and altmetric indices for MND studies in SEA}

Out of the 196 articles on MNDs included, 193 were published in journals with IF. Singapore $(n=129)$, Malaysia $(n=$ $26)$ and Thailand $(n=18)$ had the highest numbers of publications in journals with IF (see Table 2). These countries also took the lead in terms of the number of Scopus citations ( $\mathrm{n}=$ 8,$400 ; n=747$; and $n=315$, respectively). In terms of altmetric indices, Singapore had the highest numbers of PlumX citations ( $n=5,848)$, PlumX captures $(n=20,441)$, PlumX mentions $(n=$ $109)$ and PlumX social media posts $(n=2,097)$. Malaysia had the highest aggregate PlumX usage $(\mathrm{n}=32,229)$. No records on MNDs published by authors in Brunei, Cambodia, Myanmar or Timor-Leste were obtained.

A separate tabulation of indices of studies on ALS alone is presented in Table 3. Singapore and Malaysia still lead the SEA nations in terms of the scientometric indices considered.

\section{Associations between socioeconomic factors and bibliometric indices}

Correlations among the data revealed that there was a significant positive correlation between the socioeconomic indices of GDP per capita (USD) and \%GDP for research/ development $(\mathrm{R} \& \mathrm{D})$ and all the bibliometric and altmetric indices considered ( $p$-value < 0.1) (see Table 4). The number of neurologists per one million population also had a strong positive correlation with all the bibliometric and altmetric indices considered except for PlumX usage ( $p$-value $=0.103$ ). The pooled analysis did not show any significant positive or negative correlation between the socioeconomic indices of the population and the number of neurologists and the research metrics considered (p-value > 0.1).

A separate correlation of scientometric indices of ALS studies and socioeconomic indices is presented in Table 5. Similar correlation patterns were observed: strong positive relationships between the GDP per capita, \%GDP for R\&D and number of neurologists per one million population and the scientometric indices considered. 


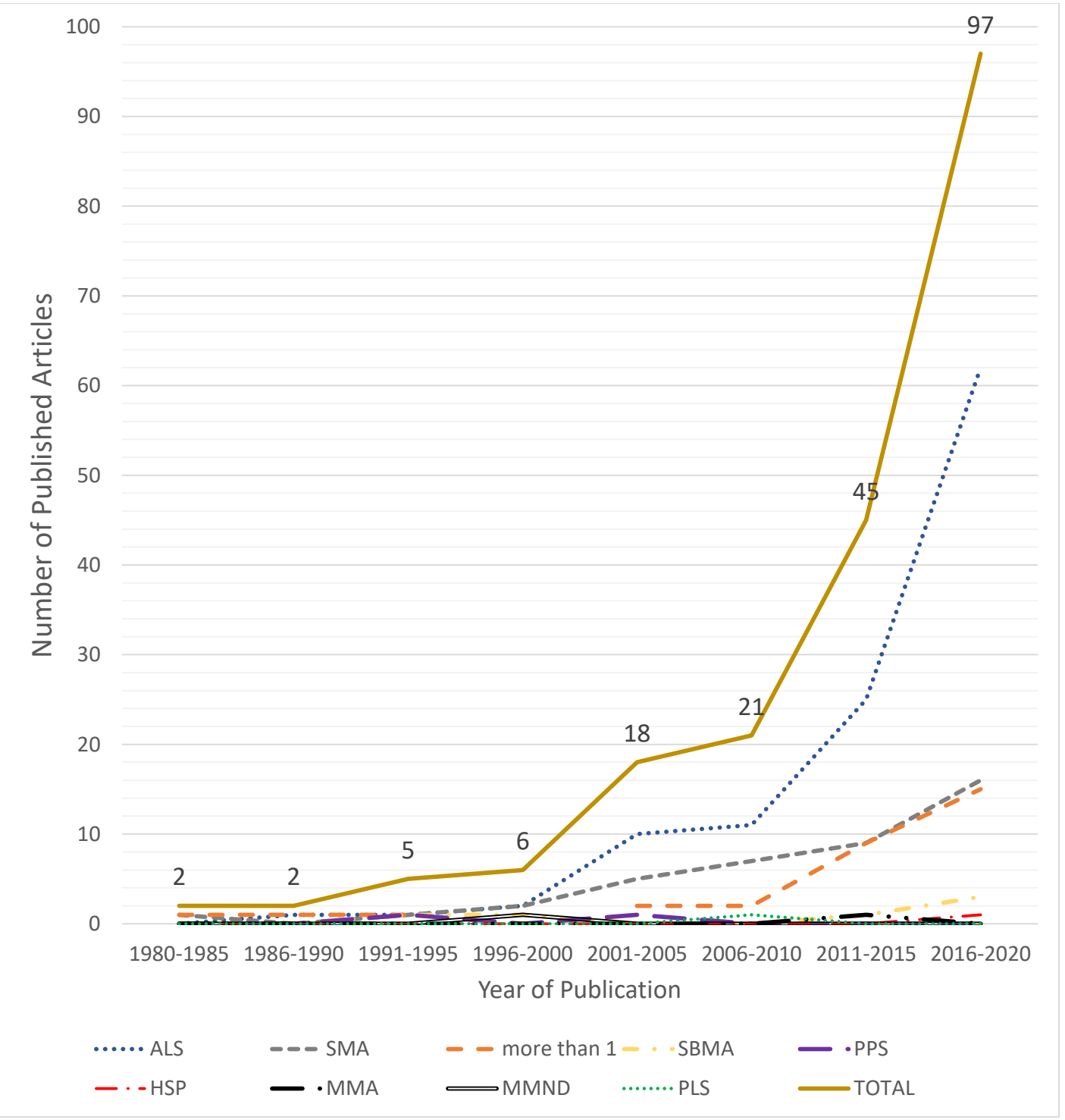

Figure 2. Trend of published articles in SEA in terms of type of MND from 1980 to 2020.

Table 1. Summary of selected socioeconomic indices in SEA countries.

\begin{tabular}{|c|c|c|c|c|c|c|}
\hline SEA country & $\begin{array}{l}2019 \text { population } \\
\text { (millions) }\end{array}$ & $\begin{array}{c}2019 \text { GDP } \\
\text { (millions, USD) }\end{array}$ & $\begin{array}{l}\text { GDP per capita } \\
\text { (USD) }\end{array}$ & $\begin{array}{c}\% \text { of GDP for } \\
\text { R\&D }\end{array}$ & $\begin{array}{c}\text { No. of } \\
\text { neurologists }\end{array}$ & $\begin{array}{l}\text { No. of neurologists per } \\
1 \text { million population }\end{array}$ \\
\hline Brunei & 0.43 & $13,469.42$ & $31,086.8$ & $0.25 \%^{f}$ & 2 & 4.65 \\
\hline Cambodia & 16.48 & $27,089.39$ & $1,643.1$ & $0.12 \%^{\mathrm{b}}$ & 5 & 0.30 \\
\hline Indonesia & 270.63 & $1,119,190.78$ & 4,135.6 & $0.23 \%{ }^{e}$ & 1,150 & 4.25 \\
\hline Laos & 7.17 & $18,173.84$ & $2,534.9$ & $0.04 \%{ }^{a}$ & 3 & 0.41 \\
\hline Malaysia & 31.95 & $364,701.52$ & $11,414.8$ & $1.44 \%^{\circ}$ & 120 & 3.76 \\
\hline Myanmar & 54.05 & $76,085.85$ & $1,407.8$ & $0.03 \%^{d}$ & 23 & 0.43 \\
\hline Philippines & 108.17 & $376,795.51$ & $3,485.1$ & $0.16 \%^{b}$ & 506 & 4.68 \\
\hline Singapore & 5.70 & $372,062.53$ & $65,233.3$ & $1.94 \%^{d}$ & 100 & 17.54 \\
\hline Thailand & 69.63 & $543,649.98$ & $7,808.2$ & $1.00 \%{ }^{d}$ & 645 & 9.26 \\
\hline Timor-Leste & 1.29 & $1,673.54$ & $1,294.2$ & no data & 0 & 0.00 \\
\hline Vietnam & 96.46 & $261,921.24$ & $2,715.3$ & $0.53 \%{ }^{d}$ & 800 & 8.29 \\
\hline TOTAL & 661.96 & $3,174,813.60$ & $(-)$ & $(-)$ & 3,354 & $(-)$ \\
\hline
\end{tabular}

GDP: gross domestic product; R\&D: research and development; SEA: Southeast Asia; USD: United States dollar; ${ }^{\text {a2}} 2002$ estimate; ${ }^{2} 2015$ estimate; ${ }^{c} 2016$ estimate, d2017 estimate, ${ }^{2} 2018$ estimate, ${ }^{f} 2019$ estimate. 
Table 2. Summary of bibliometric and altmetric indices for studies on MND in SEA.

\begin{tabular}{|c|c|c|c|c|c|c|c|}
\hline \multirow[b]{2}{*}{ Countries } & \multicolumn{2}{|c|}{ Bibliometric indices } & \multicolumn{5}{|c|}{ Altmetric indices } \\
\hline & $\begin{array}{c}\text { Total } \\
\text { number of } \\
\text { publications } \\
\text { in journals } \\
\text { with IF (\%) }\end{array}$ & $\begin{array}{c}\text { Scopus } \\
\text { citations (\%) }\end{array}$ & $\begin{array}{c}\text { PlumX } \\
\text { citations (\%) }\end{array}$ & $\begin{array}{c}\text { PlumX } \\
\text { usage (\%) }\end{array}$ & $\begin{array}{c}\text { PlumX } \\
\text { captures (\%) }\end{array}$ & $\begin{array}{c}\text { PlumX } \\
\text { mentions (\%) }\end{array}$ & $\begin{array}{c}\text { PlumX } \\
\text { social media } \\
\text { posts (\%) }\end{array}$ \\
\hline$n$ & 193 & 9,853 & 6,863 & 68,050 & 27,166 & 136 & 2,362 \\
\hline Brunei & 0 & 0 & 0 & 0 & 0 & 0 & 0 \\
\hline Cambodia & 0 & 0 & 0 & 0 & 0 & 0 & 0 \\
\hline Indonesia & $7(3.62 \%)$ & $177(1.80 \%)$ & $137(2.00 \%)$ & $136(0.20 \%)$ & $547(2.01 \%)$ & $2(1.47 \%)$ & $10(0.42 \%)$ \\
\hline Laos & $1(0.51 \%)$ & $7(0.07 \%)$ & $6(0.09 \%)$ & $3,549(5.22 \%)$ & $89(0.33 \%)$ & 0 & $7(0.30 \%)$ \\
\hline Malaysia & $26(13.47 \%)$ & $747(7.58 \%)$ & $504(7.34 \%)$ & $32,229(47.36 \%)$ & $3,838(14.13 \%)$ & $13(9.56 \%)$ & 207 (8.76\%) \\
\hline Myanmar & 0 & 0 & 0 & 0 & 0 & 0 & 0 \\
\hline Philippines & $6(3.11 \%)$ & $117(1.19 \%)$ & $73(1.06 \%)$ & $147(0.22 \%)$ & $552(2.03 \%)$ & $4(2.94 \%)$ & $10(0.42 \%)$ \\
\hline Singapore & $129(66.84 \%)$ & $8,400(85.25 \%)$ & $5,848(85.21 \%)$ & $30,215(44.40 \%)$ & $20,441(75.24 \%)$ & 109 (80.15\%) & 2,097 (88.78\%) \\
\hline Thailand & $18(9.33 \%)$ & $315(3.20 \%)$ & $224(3.26 \%)$ & $1,300(1.91 \%)$ & $1,076(3.96 \%)$ & $7(5.15 \%)$ & $22(0.93 \%)$ \\
\hline Timor-Leste & 0 & 0 & 0 & 0 & 0 & 0 & 0 \\
\hline Vietnam & $6(3.11 \%)$ & $90(0.91 \%)$ & $71(1.03 \%)$ & $564(0.83 \%)$ & $623(2.29 \%)$ & $1(0.74 \%)$ & $9(0.38 \%)$ \\
\hline
\end{tabular}

IF: impact factor; MND: motor neuron diseases; SEA: Southeast Asia.

Table 3. Summary of bibliometric and altmetric indices for studies on ALS (excluding case reports/case series) in SEA.

\begin{tabular}{|c|c|c|c|c|c|c|c|}
\hline \multirow[b]{2}{*}{ Countries } & \multicolumn{2}{|c|}{ Bibliometric Indices } & \multicolumn{5}{|c|}{ Altmetric Indices } \\
\hline & $\begin{array}{c}\text { Total } \\
\text { publications } \\
\text { in journals } \\
\text { with IF (\%) }\end{array}$ & $\begin{array}{c}\text { Scopus } \\
\text { Citations (\%) }\end{array}$ & $\begin{array}{c}\text { PlumX } \\
\text { Citations (\%) }\end{array}$ & PlumX Usage (\%) & $\begin{array}{c}\text { PlumX } \\
\text { Captures (\%) }\end{array}$ & $\begin{array}{c}\text { PlumX } \\
\text { Mentions (\%) }\end{array}$ & $\begin{array}{l}\text { PlumX Social } \\
\text { media (\%) }\end{array}$ \\
\hline$n$ & 119 & 6,489 & 4,609 & 40,883 & 19,075 & 66 & 1,309 \\
\hline Brunei & 0 & 0 & 0 & 0 & 0 & 0 & 0 \\
\hline Cambodia & 0 & 0 & 0 & 0 & 0 & 0 & 0 \\
\hline Indonesia & $5(4.20 \%)$ & $177(2.73 \%)$ & $137(2.97 \%)$ & $136(0.33 \%)$ & $524(2.75 \%)$ & $2(3.03 \%)$ & $10(0.76 \%)$ \\
\hline Laos & $1(0.84 \%)$ & $7(0.11 \%)$ & $6(0.13 \%)$ & $3,549(8.68 \%)$ & $89(0.47 \%)$ & 0 & $7(0.53 \%)$ \\
\hline Malaysia & $12(10.08 \%)$ & $378(5.83 \%)$ & $255(5.53 \%)$ & 20,168 (49.33\%) & $2,686(14.08 \%)$ & $4(6.06 \%)$ & $176(13.45 \%)$ \\
\hline Myanmar & 0 & 0 & 0 & 0 & 0 & 0 & 0 \\
\hline Philippines & $5(4.20 \%)$ & $86(1.33 \%)$ & $55(1.19 \%)$ & $142(0.35 \%)$ & $421(2.21 \%)$ & $4(6.06 \%)$ & $7(0.53 \%)$ \\
\hline Singapore & $88(73.95 \%)$ & $5,665(87.30 \%)$ & $4,040(87.65 \%)$ & $16,261(39.77 \%)$ & $15,057(78.94 \%)$ & $55(83.33 \%)$ & $1,104(84.34 \%)$ \\
\hline Thailand & $6(9.33 \%)$ & $175(2.70 \%)$ & $116(2.52 \%)$ & $507(1.24 \%)$ & $241(1.26 \%)$ & $1(1.52 \%)$ & $5(0.38 \%)$ \\
\hline Timor-Leste & 0 & 0 & 0 & 0 & 0 & 0 & 0 \\
\hline Vietnam & $2(1.68 \%)$ & $1(0.02 \%)$ & $0(0 \%)$ & $120(0.29 \%)$ & $57(0.30 \%)$ & $0(0 \%)$ & $0(0 \%)$ \\
\hline
\end{tabular}

IF: impact factor; ALS: amyotrophic lateral sclerosis.

Table 4. Correlation between socioeconomic indices of SEA countries and bibliometric and altmetric indices of MND publications in SEA.

\begin{tabular}{|c|c|c|c|}
\hline Socioeconomic Indices & Bibliometric and altmetric indices & Pearson's R & P-value \\
\hline \multirow[t]{7}{*}{2019 population (million) } & $\begin{array}{c}\text { Total number of publications in } \\
\text { journals with IF }\end{array}$ & -0.187 & 0.581 \\
\hline & Scopus citations & -0.216 & 0.524 \\
\hline & PlumX citations & -0.214 & 0.528 \\
\hline & PlumX usage & -0.270 & 0.422 \\
\hline & PlumX captures & -0.218 & 0.520 \\
\hline & PlumX mentions & -0.217 & 0.522 \\
\hline & PlumX social media posts & -0.235 & 0.487 \\
\hline
\end{tabular}


Table 4. Cont.

\begin{tabular}{|c|c|c|c|}
\hline Socioeconomic Indices & Bibliometric and altmetric indices & Pearson's R & P-value \\
\hline \multirow[t]{7}{*}{$\begin{array}{l}2019 \text { gross domestic product per } \\
\text { capita (USD) }\end{array}$} & $\begin{array}{c}\text { Total number of publications in } \\
\text { journals with IF }\end{array}$ & 0.885 & $0.000 *$ \\
\hline & Scopus citations & 0.899 & $0.000 *$ \\
\hline & PlumX citations & 0.899 & $0.000 *$ \\
\hline & PlumX usage & 0.630 & $0.038^{*}$ \\
\hline & PlumX captures & 0.893 & $0.000^{*}$ \\
\hline & PlumX mentions & 0.897 & $0.000 *$ \\
\hline & PlumX social media posts & 0.900 & $0.000 *$ \\
\hline \multirow[t]{7}{*}{$\%$ gross domestic product for R\&D } & $\begin{array}{c}\text { Total number of publications in } \\
\text { journals with IF }\end{array}$ & 0.849 & $0.002^{*}$ \\
\hline & Scopus citations & 0.775 & $0.008^{*}$ \\
\hline & PlumX citations & 0.774 & $0.009 *$ \\
\hline & PlumX usage & 0.876 & $0.001 *$ \\
\hline & PlumX captures & 0.823 & $0.003 *$ \\
\hline & PlumX mentions & 0.795 & $0.006 *$ \\
\hline & PlumX social media posts & 0.774 & $0.009 *$ \\
\hline \multirow[t]{7}{*}{ No. of neurologists } & $\begin{array}{c}\text { Total number of publications in } \\
\text { journals with IF }\end{array}$ & -0.100 & 0.770 \\
\hline & Scopus citations & -0.152 & 0.655 \\
\hline & Plum $X$ citations & -0.149 & 0.661 \\
\hline & PlumX usage & -0.246 & 0.466 \\
\hline & PlumX captures & -0.150 & 0.660 \\
\hline & PlumX mentions & -0.148 & 0.664 \\
\hline & PlumX social media posts & -0.176 & 0.604 \\
\hline \multirow[t]{7}{*}{$\begin{array}{l}\text { No. of neurologists per } 1 \text { million } \\
\text { population }\end{array}$} & $\begin{array}{c}\text { Total number of publications in } \\
\text { journals with IF }\end{array}$ & 0.849 & $0.001 *$ \\
\hline & Scopus citations & 0.814 & $0.002^{*}$ \\
\hline & PlumX citations & 0.815 & $0.002^{*}$ \\
\hline & PlumX usage & 0.518 & 0.103 \\
\hline & PlumX captures & 0.816 & $0.002^{\star}$ \\
\hline & PlumX mentions & 0.822 & $0.002 *$ \\
\hline & PlumX social media posts & 0.800 & $0.003 *$ \\
\hline
\end{tabular}

*Correlation is significant at the 0.1 level (2-tailed); MND: motor neuron diseases; SEA: Southeast Asia; R\&D: research and development.

Table 5. Correlation between socioeconomic indices of SEA countries and bibliometric and altmetric indices of ALS publications in SEA (excluding case reports/series).

\begin{tabular}{|c|c|c|c|}
\hline Socioeconomic indices & Bibliometric and altmetric indices & Pearson's $\mathrm{R}$ & P-value \\
\hline \multirow[t]{7}{*}{2019 population (million) } & $\begin{array}{l}\text { Total number of publications in } \\
\text { journals with IF }\end{array}$ & -0.183 & 0.591 \\
\hline & Scopus citations & -0.206 & 0.544 \\
\hline & Plum $X$ citations & -0.203 & 0.549 \\
\hline & PlumX usage & -0.275 & 0.413 \\
\hline & Plum X captures & -0.214 & 0.527 \\
\hline & PlumX mentions & -0.191 & 0.574 \\
\hline & PlumX social media posts & -0.239 & 0.479 \\
\hline
\end{tabular}


Table 5. Cont.

\begin{tabular}{|c|c|c|c|}
\hline Socioeconomic indices & Bibliometric and altmetric indices & Pearson's R & P-value \\
\hline \multirow[t]{7}{*}{$\begin{array}{l}2019 \text { gross domestic product per } \\
\text { capita (USD) }\end{array}$} & $\begin{array}{c}\text { Total number of publications in } \\
\text { journals with IF }\end{array}$ & 0.892 & $<0.001^{*}$ \\
\hline & Scopus citations & 0.899 & $<0.001^{\star}$ \\
\hline & Plum $X$ citations & 0.899 & $<0.001 *$ \\
\hline & PlumX usage & 0.566 & $0.069 *$ \\
\hline & PlumX captures & 0.894 & $<0.001 *$ \\
\hline & PlumX mentions & 0.894 & $<0.001^{\star}$ \\
\hline & PlumX social media posts & 0.898 & $<0.001^{*}$ \\
\hline \multirow[t]{7}{*}{$\%$ gross domestic product for $R \& D$} & $\begin{array}{l}\text { Total number of publications in } \\
\text { journals with IF }\end{array}$ & 0.796 & $0.006^{*}$ \\
\hline & Scopus citations & 0.760 & $0.011^{*}$ \\
\hline & PlumX citations & 0.758 & $0.011^{*}$ \\
\hline & PlumX usage & 0.835 & $0.003^{*}$ \\
\hline & PlumX captures & 0.805 & $0.005^{*}$ \\
\hline & PlumX mentions & 0.750 & $0.013^{*}$ \\
\hline & PlumX social media posts & 0.797 & $0.006^{*}$ \\
\hline \multirow[t]{7}{*}{ No. of neurologists } & $\begin{array}{c}\text { Total number of publications in } \\
\text { journals with IF }\end{array}$ & -0.117 & 0.731 \\
\hline & Scopus citations & -0.147 & 0.666 \\
\hline & PlumX citations & -0.146 & 0.669 \\
\hline & PlumX usage & -0.263 & 0.435 \\
\hline & PlumX captures & -0.164 & 0.631 \\
\hline & PlumX mentions & -0.139 & 0.683 \\
\hline & PlumX social media posts & -0.186 & 0.583 \\
\hline \multirow[t]{7}{*}{$\begin{array}{l}\text { No. of neurologists per } 1 \text { million } \\
\text { population }\end{array}$} & $\begin{array}{l}\text { Total number of publications in } \\
\text { journals with IF }\end{array}$ & 0.827 & $0.002^{*}$ \\
\hline & Scopus citations & 0.810 & $0.003 *$ \\
\hline & Plum $X$ citations & 0.809 & $0.003 *$ \\
\hline & PlumX usage & 0.443 & 0.172 \\
\hline & PlumX captures & 0.796 & $0.003 *$ \\
\hline & PlumX mentions & 0.808 & $0.003 *$ \\
\hline & PlumX social media posts & 0.791 & $0.004^{\star}$ \\
\hline
\end{tabular}

${ }^{*}$ Correlation is significant at the 0.1 level (2-tailed); ALS: amyotrophic lateral sclerosis; R\&D: research and development; IF: impact factor.

\section{DISCUSSION}

To the best of our knowledge, this was the first study investigating the MND research productivity of SEA countries and its correlation with socioeconomic variables. We methodically gathered MND studies authored by experts in the different SEA institutions, starting from the earliest indexed records of the major research databases. We included all forms of study designs and research domains. To evaluate the impact of the studies included, we obtained traditional research metrics (numbers of publications in journals with IF and numbers of Scopus citations), as well as alternative metrics (PlumX metrics). To correlate the research metrics with socioeconomic variables, we obtained the latest estimates and determinations of populations, GDP, GDP per capita, \%GDP allocated for research and development and the number of practicing neurologists in each of the SEA countries.

Since 1980, there has been consistent growth in terms of the numbers of MND research publications in this region. This may have been due to both economic growth and increasing use of information technology in SEA ${ }^{23}$. Nonetheless, there is paucity in the number of randomized trials on MNDs in this region. This may be due to several factors that have deterred clinical trialists and funding institutions from conducting controlled trials in this region. These could include the following: (a) regulatory issues such as delays in attainment of ethical approvals, prohibition of first-in-man studies in certain countries and stringent drug importation regulations; (b) issues relating 
to infrastructure, such as a lack of accredited laboratories; (c) operational issues such as major differences in terms of local and international guidelines on good clinical practice; and (d) cultural concerns such as difficulty in obtaining informed consent among members of certain Asian cultures ${ }^{24}$.

The majority of the studies dealt with pathophysiology (n $=99 ; 50.5 \%)$ and treatment $(n=36 ; 18.4 \%)$. This may have been due to the growing interest of researchers in reaching better understanding of incurable disease, particularly ALS, given that the prevalence of ALS is expected to increase by $69 \%$ by the year 2040, consequent to aging of populations ${ }^{25}$.

The overall MND research productivity is continuously growing ${ }^{26,27}$; however, no other study had examined its correlation with economic indices. The present study highlighted that MND research productivity is linked to economic growth. Our analysis demonstrated that among the SEA countries, Singapore, Malaysia and Thailand had the highest GDP per capita and \%GDP allocation to research and development. Consequently, these three countries consistently dominate MND research productivity in all the bibliometric and altmetric indices considered. These countries have robust economic action plans that allow them to effectively transition to information technology-driven, human resource development-centered, knowledge-based economies: Singapore (Industry 21); Malaysia (Industrial Master Plan and Vision 2020); and Thailand (Thailand IT2000) ${ }^{28-30}$. The correlation between economic variables and scientific productivity has also been demonstrated in research on other disease conditions: GDP and respiratory disease research output ${ }^{31}$; GDP and gastric cancer research productivity $^{32}$; GDP and public health research output ${ }^{33}$; GDP and transplant research ${ }^{34}$; and GDP and scientific output on cerebrovascular rehabilitation $^{35}$. In SEA, this trend was consistently manifested in other bibliometric studies comparing research productivity relating to other neurological diseases and economic indices: multiple sclerosis and neuromyelitis optica spectrum disorder ${ }^{36}$, dementia ${ }^{37}$, cerebrovascular diseases $^{38}$, movement disorders ${ }^{39}$, bacterial central nervous system infection ${ }^{40}$ and primary brain tumors ${ }^{41}$. The nature of causality in this correlation, however, should be carefully considered. The relationship between economic growth and general publication productivity in Asia and the Pacific and other prominent economies such as the United States, Italy, Spain, Australia,
India, Netherlands, Brazil, Switzerland, Taiwan and Poland is actually bi-directional: economic growth promotes research expenditure and output and vice versa ${ }^{42}$.

Our analysis also demonstrated that there was a strong positive correlation between the total number of neurologists per one million population and scientific productivity in terms of the bibliometric and altmetric indices considered. The total number of neurologists or experts was a separate contributor to scientific productivity, independent of economic influences. This was supported by a cohort study that demonstrated that adjusted research productivity in terms of longitudinal publishing trajectories between neurologists without federal research funding and physician-scientists with federal R01 research grants were not significantly different ${ }^{43}$.

One potential limitation of this study was its reliance on conventional bibliometric and altmetric indices. The majority of the economies in SEA belong to low and middle-income categories. Conventional research metrics may not be an ideal gauge of research productivity in these resource-limited settings because there is a general paucity of effective healthcare systems, limited access to scientific literature, lack of funding for research and development, very limited protected time for research and a different cultural context ${ }^{44}$. More contextsensitive metrics, including the level of translation of research evidence into actual practice, research dissemination and degree of collaboration, are recommended. Another potential limitation of this study was the lack of consideration for intercountry research collaboration, given that the indices were measured per individual country. Future studies on scientific productivity in SEA should take into account inter-country research collaboration.

In conclusion, MND research productivity in SEA is continuously growing. Singapore, Malaysia and Thailand, the countries with the highest GDP and \%GDP for R\&D in SEA, contributed the most to MND research output, as shown by their scores in the research metrics included. Strong positive correlations were demonstrated between the socioeconomic indices of GDP per capita (USD), \%GDP for R\&D and number of neurologists per one million population, and most of the bibliometric and altmetric indices. This highlights the potential role of improving economic indices as well as the number of neurologists, in advancing scientific output on MNDs in SEA.

\section{REFERENCES}

1. GBD 2016 Motor Neuron Disease Collaborators. Global, regional, and national burden of motor neuron diseases 1990-2016: a systematic analysis for the Global Burden of Disease Study 2016. Lancet Neurol. 2018 Dec 1;17(12):P1083-97. https://doi.org/10.1016/S14744422(18)30404-6

2. Swash M, Desai J. Motor neuron disease: classification and nomenclature. Amyotroph Lateral Scler Other Motor Neuron Disord. 2000 Mar;1(2):105-12. https://doi.org/10.1080/14660820050515403
2009 Sep;67(3A):750-82. https://doi.org/10.1590/S0004282X2009000400040

4. Manzano R, Sorarú G, Grunseich C, Fratta P, Zuccaro E, Pennuto $M$, et al. Beyond motor neurons: expanding the clinical spectrum in Kennedy's disease. J Neurol Neurosurg Psychiatry. 2018 Aug;89(8):808-12. https://doi.org/10.1136/jnnp-2017-316961

5. Pinto WBVR, Debona R, Nunes PP, Assis ACD, Lopes CG, Bortholin $T$, et al. Atypical motor neuron Disease variants: still a diagnostic challenge in neurology. Rev Neurol (Paris). 2019 Apr;175(4):221-32. https://doi.org/10.1016/j.neurol.2018.04.016 
6. Palese F, Sartori A, Verriello L, Ros S, Passadore P, Manganotti P, et al. Epidemiology of amyotrophic lateral sclerosis in Friuli-Venezia Giulia, North-Eastern Italy, 2002-2014: a retrospective populationbased study. Amyotroph Lateral Scler Frontotemporal Degener. 2019 Feb;20(1-2):90-9. https://doi.org/10.1080/21678421.2018.1511732

7. Benjaminsen E, Alstadhaug KB, Gulsvik M, Baloch FK, Odeh F. Amyotrophic lateral sclerosis in Nordland county, Norway, 20002015: prevalence, incidence, and clinical features. Amyotroph Lateral Scler Frontotemporal Degener. 2018 Nov;19(7-8):522-7. https://doi.or g/10.1080/21678421.2018.1513534

8. Stoyas CA, La Spada AR. The CAG-polyglutamine repeat diseases: a clinical, molecular, genetic, and pathophysiologic nosology. In: Geschwind DH, Paulson HL, Klein C, editors. Neurogenetics, part I. 1st ed. Elsevier; 2018. p. 143-70.

9. Ragonese P, Fierro B, Salemi G, Randisi G, Buffa D, D’Amelio M, et al. Prevalence and risk factors of post-polio syndrome in a cohort of polio survivors. J Neurol Sci. 2005 Sep 15;236(1-2):P31-5. https://doi. org/10.1016/j.jns.2005.04.012

10. Shahrizaila N, Sobue G, Kuwabara S, Kim SH, Birks C, Fan DS, et al. Amyotrophic lateral sclerosis and motor neuron syndromes in Asia. J Neurol Neurosurg Psychiatry. 2016 Aug;87(8):821-30. https://doi. org/10.1136/jnnp-2015-312751

11. Mingers J, Leydesdorff L. A review of theory and practice in scientometrics. Eur J Oper Res. 2015 Oct 1;246(1):1-19. https://doi. org/10.1016/j.ejor.2015.04.002

12. Grech $V$, Rizk DEE. Increasing importance of research metrics: journal impact factor and h-index. Int Urogynecol J. 2018 May;29(5):619-20. https://doi.org/10.1007/s00192-018-3604-8

13. Champieux R. PlumX.J Med Libr Assoc. 2015 Jan;103(1):63-4. https:// doi.org/10.3163/1536-5050.103.1.019

14. Ellegaard O, Wallin JA. The bibliometric analysis of scholarly production: How great is the impact? Scientometrics. 2015 Dec;105(3):1809-31. https://doi.org/10.1007/s11192-015-1645-z

15. Bayarçelik EB, Taşel F. Research and development: source of economic growth. Procedia Soc Behav Sci. 2012 Oct 12;58:744-53. https://doi.org/10.1016/j.sbspro.2012.09.1052

16. Meo SA, Al Masri AA, Usmani AM, Memon AN, Zaidi SZ. Impact of GDP, spending on R\&D, number of universities and scientific journals on research publications among Asian countries. Plos One. 2013 Jun 20;8(6):e66449. https://doi.org/10.1371/journal.pone.0066449

17. Elsevier [Internet]. Scopus Database. Published 2020; [cited 2020 Aug 1]. Available from: https://www.scopus.com

18. Elsevier [Internet]. PlumX Analytics. Published 2020; [cited 2020 Aug 1]. Available from: https://plu.mx/

19. Clarivate Analystics [Internet]. Journal Citation Reports. Published 2020; [cited 2020 Aug 1]. Available from: https://incites.clarivate. $\mathrm{com} /$

20. Lindsay JM. PlumX from plum analytics: not just altmetrics. J Electron Resour Med Libr. 2016 Apr 15;13(1):8-17. https://doi.org/10.1 080/15424065.2016.1142836

21. World Bank Group. The World Bank Open Data. Published 2020; [cited 2020 Aug 10]. Available from: https://data.worldbank.org

22. Roxas Jr A, Mehndiratta MM, Bornstein N, Macdonell R, Lim KS, Ng $\mathrm{P}-\mathrm{W}$, et al. The professional practice and training of neurology in the Asian and Oceanian Region: a cross-sectional survey by the Asian and Oceanian Association of Neurology (AOAN). J Neurol Sci. 2017 Nov 15;382:P108-15. https://doi.org/10.1016/j.jns.2017.09.022

23. Gholizadeh H, Salehi H, Embi MA, Danaee M, Ordi A, Tanha F, et al. Economic growth and internet usage impact on publication productivity among ASEAN's and world's best universities. Mod Appl Sci. 2014;8(5):169. https://doi.org/10.5539/mas.v8n5p169

24. Ali S, Egunsola O, Babar ZUD, Hasan SS. Challenges of conducting clinical trials in Asia. Int J Clin Trials. 2018 Oct-Dec;5(4):194. https:// doi.org/10.18203/2349-3259.ijct20183748

25. Arthur KC, Calvo A, Price TR, Geiger JT, Chiò A, Traynor BJ. Projected increase in amyotrophic lateral sclerosis from 2015 to 2040. Nat Commun. 2016 Aug 11;7:12408. https://doi.org/10.1038/ ncomms 12408

26. Ram S. A bibliometric assessment of global ice bucket challenge (amyotrophic lateral sclerosis) research. Ann Neurosci. 2016 Oct;23(4):209-17. https://doi.org/10.1159/000449481
27. Quansah E, Karikari TK. Motor neuron diseases in Sub-Saharan Africa: The need for more population-based studies. Biomed Res Int. 2015;2015:298409. https://doi.org/10.1155/2015/298409

28. Bhatiasevi $\mathrm{V}$. The race towards a knowledge based economy: A comparative study between Malaysia and Thailand. Int J Bus Manag. 2010;5(1):114-22. https://doi.org/10.5539/ijbm.v5n1p114

29. Science Technology Industry. Knowledge-based Industries in Asia [Internet]. OECD; 2000.73p. [cited 2020 Aug 01] Available from: https://www.oecd.org/countries/malaysia/2090653.pdf

30. Tan HB, Hooy CW. The development of East Asian countries towards a knowledge-based economy: a DEA analysis. J Asia Pacific Econ. 2007 Jan 29;12(1):17-33. https://doi.org/10.1080/13547860601083538

31. Qu Y, Zhang C, Hu Z, Ning Y, Kong C, Shang Y, et al. Bibliometric analysis of scientific publications in respiratory journals from China and other top-ranking countries between 2007 and 2017. Clin Respir J. 2019 Jan;13(1):50-7. https://doi.org/10.1111/crj.12980

32. Klingelhöfer D, Braun M, Schöffel N, Brüggmann D, Groneberg DA. Gastric cancer: bibliometric analysis of epidemiological, geographical and socio-economic parameters of the global research landscape. Int J Health Policy Manag. 2021 Mar 1;10(3):118-28. https://doi. org/10.34172/IJHPM.2020.29

33. Clarke A, Gatineau M, Grimaud O, Royer-Devaux S, Wyn-Roberts $\mathrm{N}$, Le Bis I, et al. A bibliometric overview of public health research in Europe. Eur J Public Health. 2007;17 Suppl 1:43-9. https://doi. org/10.1093/eurpub/ckm063

34. Pu Q-H, Lyu Q-J, Su H-Y. Bibliometric analysis of scientific publications in transplantation journals from Mainland China, Japan, South Korea and Taiwan between 2006 and 2015. BMJ Open. 2016 Aug 3;6(8):e011623. https://doi.org/10.1136/bmjopen-2016-011623

35. Ugolini D, Neri M, Cesario A, Marazzi G, Milazzo D, Volterrani M, et al. Bibliometric analysis of literature in cerebrovascular and cardiovascular diseases rehabilitation: growing numbers, reducing impact factor. Arch Phys Med Rehabil. 2013 Feb 1;94(2):P324-31.E1. https://doi.org/10.1016/j.apmr.2012.08.205

36. Espiritu Al, Leochico CFD, Separa KJNJ, Jamora RDG. Scientific impact of multiple sclerosis and neuromyelitis optica spectrum disorder research from Southeast Asia: a bibliometric analysis. Mult Scler Relat Disord. 2020 Feb 1;38:101862. https://doi.org/10.1016/j. msard.2019.101862

37. Sy MCC, Espiritu Al, Sy MSC, Jamora RDG, Anlacan VMM. Dementia research productivity and associations with socioeconomic factors and burden of disease in Southeast Asia. J Alzheimers Dis. 2020;76(3):1151-60. https://doi.org/10.3233/JAD-200355

38. Apor ADAO, Pagaling GT, Espiritu Al, Jamora RDG. Stroke research disparity in Southeast Asia: socioeconomic factors, healthcare delivery, and stroke disease burden. J Stroke Cerebrovasc Dis. 2021 Feb 1;30(2):105481. https://doi.org/10.1016/j. jstrokecerebrovasdis.2020.105481

39. Pajo AT, Espiritu Al, Jamora RDG. Scientific impact of movement disorders research output in Southeast Asian countries: a bibliometric analysis. Parkinsonism Relat D. 2020 Dec 1;81:P205-12. https://doi.org/10.1016/j.parkreldis.2020.10.043

40. Jalipa FGU, Sy MCC, Espiritu Al, Jamora RDG. Bibliometric analysis of bacterial central nervous system infection research in Southeast Asia. BMC Neurol. 2021 Jan 8;21(1):11. https://doi.org/10.1186/ s12883-021-02042-w

41. Mondia MWL, Espiritu Al, Jamora RDG. Primary brain tumor research productivity in Southeast Asia and its association with socioeconomic determinants and burden of disease. Front Oncol. 2020 Dec 23;10:607777. https://doi.org/10.3389/fonc.2020.607777

42. Zaman K, Khan HUR, Ahmad M, Aamir A. Research productivity and economic growth: a policy lesson learnt from across the globe. Iran Econ Rev. 2018;22(3):627-41. https://doi.org/10.22059/ ier.2018.66633

43. Bensken WP, Hansen AK, Norato G, Heiss JD, Nath A, Khan OI. Physician-scientists in neurology. Neurology. 2018 Sep 11;91(11):508-14. https://doi.org/10.1212/01. wnl.0000544243.58941.11

44. Ekeroma AJ, Shulruf B, McCowan L, Hill AG, Kenealy T. Development and use of a research productivity assessment tool for clinicians in low-resource settings in the Pacific Islands: a Delphi study. Health Res Policy Syst. 2016 Jan 29;14:9. https://doi.org/10.1186/s12961016-0077-4 